\title{
Study of the Cryopreservation Conditions for seed Materials of Chartolepis intermedia Boiss.
}

\author{
Margarita Ishmuratova*, Saltanat Tleukenova, Alibek Ramasanov, Elena Gavrilkova, and \\ Dmitrii Ageev \\ Karaganda University named after academician E.A. Buketov, 100028 Karaganda, Republic of \\ Kazakhstan
}

\begin{abstract}
For the first time, the depending of germination rate and energy of germination of Chartolepis intermedia seeds, collected in the wild of Karaganda region, from morphology of seeds and conditions of cryopreservation is investigated. The maximum results for viability are fixed for dark-colored average or large seeds. The best results are determined for variant of cryopreservation in plastic container with future defrosting at the room temperature. For the increasing parameters of seed germination we recommended to freeze Chartolepis intermedia seeds with using cryoprotector sucrose in concentration $20 \%$. As the results of the study, we developed algorithm of cryopreservation of Chartolepis intermedia seeds in liquid nitrogen.
\end{abstract}

\section{Introduction}

Republic of Kazakhstan has a rich diversity of medicinal plants: from 5500 species of vascular plants [1] accordantly 1200 species have medicinal properties [2]. Not all plants are suitable for collected in nature due their rarity, lack of vegetative resources and remoteness of natural populations. One the optimal decision is introduction medicinal plants for future industrial cultivation $n$ production of required volumes of raw material [3]. In process of introduction experiment is necessary to develop effective methods for the cryopreservation of seed materials of prospect herbs [4]. Present day the most optimal method for storage of gene pool is cryopreservation, which allows storing seed material for a long period without loss of viability $[5,6]$.

The purpose of the present study is to determine optimal methods for cryopreservation of seed material of perspective medicinal plant - Chartolepis intermedia.

\section{Materials and methodology}

\subsection{Objects}

*Corresponding author: margarita.ishmur@mail.ru 
Chartolepis intermedia Boiss. is a perennial herbal plants from Asteraceae family, grows in alkaline (salty) and steppe meadows, in steppe declines, river floodplains, along streams, in the vicinity of settlements [1,7]. Biological active compounds from areal part have antibacterial, antiviral and inflammatory activity [8], which has the potential for developing the new domestic phytopreparations [9].

Seed material for the study is collected in Spassky hills (Karaganda region; N 49,49106; E $73,23768)$, phase - heavy bearing.

\subsection{Assessment of seed viability}

Seeds of Chartolepis intermedia are frozen in the liquid nitrogen in the Dewar vessels using foil and plastic containers [10]. Assessment of germination rage and energy of germination are conducted on Petri dishes during 3 weeks [11]. For optimization storage conditions different defrosting methods (fast - on water bath, $+40{ }^{\circ} \mathrm{C}$; slow - at the room temperature, $+24^{\circ} \mathrm{C}$ ) and cryoprotectors are evaluated.

\section{Results}

Seed of Chartolepis intermedia is mericarp, length 5-6 mm, width $1.6-2 \mathrm{~mm}$, weight of 1000 seeds is 3.5-5 gram. They differ in size, color and weight, which depend on placement in flower baskets and time of ripening. The different variants showed different indicators of germination rate and energy of germination (Table 1).

Table 1. The viability of Chartolepis intermedia seeds on color and size

\begin{tabular}{|c|c|c|}
\hline Variant of seed samples & Germination rate, \% & Energy of germination, \% \\
\hline White small & $2.5 \pm 0.04$ & $2.2 \pm 0.05$ \\
\hline Beige small & $20.0 \pm 0.1$ & $15.2 \pm 0.1$ \\
\hline Brown average & $67.5 \pm 2.5$ & $42.5 \pm 0.8$ \\
\hline Brown large & $72.5 \pm 3.2$ & $52.5 \pm 2.7$ \\
\hline
\end{tabular}

Results influence type of containers and method of defrosting on viability of Chartolepis intermedia seeds is presented in table 2, influence of cryoprotectors - in table 3 .

Table 2. Germination of Chartolepis intermedia seeds depending on the type of containers and method of defrosting

\begin{tabular}{|c|c|c|}
\hline Variant of experience & Germination rate, \% & Energy of germination, \% \\
\hline $\begin{array}{c}\text { Plastic tubes, slow } \\
\text { defrosting }\end{array}$ & $50.0 \pm 1.8$ & $37.5 \pm 0.4$ \\
\hline $\begin{array}{c}\text { Foil package, slow } \\
\text { defrosting }\end{array}$ & $42.5 \pm 0.9$ & $32.5 \pm 0.6$ \\
\hline $\begin{array}{c}\text { Plastic tubes, fast } \\
\text { defrosting }\end{array}$ & $47.5 \pm 0.8$ & $27.5 \pm 0.5$ \\
\hline $\begin{array}{c}\text { Foil package, fast } \\
\text { defrosting }\end{array}$ & $45.0 \pm 0.6$ & $28.3 \pm 0.4$ \\
\hline
\end{tabular}

Table 3. Germination of Chartolepis intermedia seeds depending on the type of containers and method of defrosting 


\begin{tabular}{|c|c|c|}
\hline $\begin{array}{c}\text { Cryoprotector, } \\
\text { concentration }\end{array}$ & Germination rate, \% & Energy of germination, \% \\
\hline Sucrose, 5\% & $67.5 \pm 3.2$ & $42.5 \pm 0.7$ \\
\hline Sucrose, 10\% & $55.0 \pm 1.9$ & $20.0 \pm 0.8$ \\
\hline Sucrose, 15\% & $62.5 \pm 3.2$ & $32.6 \pm 0.5$ \\
\hline Sucrose, 20\% & $70.2 \pm 3.5$ & $37.6 \pm 0.4$ \\
\hline $\begin{array}{c}\text { Glucose 5\% + Glycerine } \\
40 \%\end{array}$ & $62.5 \pm 2.5$ & $27.6 \pm 0.3$ \\
\hline $\begin{array}{c}\text { Glucose 25\% + Glycerine } \\
40 \%\end{array}$ & $27.5 \pm 0.1$ & $12.5 \pm 0.07$ \\
\hline $\begin{array}{c}\text { Glucose 45\% Glycerine } \\
40 \%\end{array}$ & $45.0 \pm 0.8$ & $20.3 \pm 0.1$ \\
\hline
\end{tabular}

\section{Discussion}

For Chartolepis intermedia seeds is note that germination dependence on size and. So, the best results are obtained for dark-colored seeds of average or large size (67.5-72.5\%). There, for the laying seeds for the storage, it is necessary to take out a large fraction.

The results of freezing of Chartolepis intermedia seeds in liquid nitrogen showed that they are able to tolerate extra-critical low temperatures. Germination rate and energy of germination for seeds, frozen in plastic containers, were higher than in foil containers. In optimizing defrosting conditions, the best results are obtained for the option of freezing seeds in plastic containers and defrosting at the room temperature.

The use of cryoprotectors made it possible to establish positive results exceeding the control values for the $20 \%$ sucrose variant. So, germination rate was $70.2 \%$, energy of germination $-37.6 \%$. Based on the results of research, recommendations and an algorithm for freezing Chartolepis intermedia seeds in liquid nitrogen are developed.

Acknowledgements. The work was carried out with support of the state grant of the Committee of Science of the Ministry of Education and Science of the Republic of Kazakhstan (AP09259548).

\section{References}

1. Flora of Kazakhstan: in 9 vol. (Almaty, Nauka, 1956-1966)

2. L. M. Grudzinskaya, N. G. Gemedzhieva, N. V. Nelina, J. J. Karzhaubekova. Annotated list of medicinal plants in Kazakhstan (Almaty, 2014)

3. E. S. Vasfilova, O. E. Sushenzov, K. S. Zainullina, N. V. Potnyagina, M. G. Fomina, Perm University Bulletin 2 (2013)

4. F. Engelmann, In Vitro Cellular \& Developmental Biology - Plant, 40 (2004)

5. A. D. Rodrigo, C. Silma, A. O. Neves, M. R. Leonardo, S. N. L. Paulo, O. S. Flaviano, Industrial Crops and Products, 91 (2016)

6. A. V. Pavlov, V. G. Verzhuk, S. Yu. Orlova, O. Ye. Radchenko, M. V. Yerastenkova, A. Sh. Dodonova, Y. A. Gavrilkova, M. N. Sitnikov, G. I. Filipenko, S. V. Murashev, Probl Cryobiol Cryomed, 29(1) (2019)

7. O. N. Savidenko, S. A. Nevskii, Phytodiversity of the Eastern Europe, IX (3) (2015)

8. Plant resources of Russian: wild flowering plants, their component compositions and biological activity. Vol. 5. (SPb., Moscow, KMK, 2013) 
9. S. A. Adekenova, P. Y. Sakenova, S. A. Ivasenko, I. A. Khabarov, S. M. Adekenov, A. Berthod, Chromatographia, 79 (1-2) (2016)

10. B. M. Reed The basics of in vitro storage and cryopreservation, National Clonal Germplasm Repository (Corvallis, O.R. USA. 2002)

11. M. S. Zorina, S. P. Kabanov, Methods introduction study in Kazakhstan (Alma-Ata, Nauka, 1987) 